\title{
Changes in HMF content and diastase activity in honey after heating treatment
}

\author{
Muhammad Sajid ${ }^{1}$, Tahira Yasmin ${ }^{2}$, Farkhanda Asad ${ }^{1}$ and Samina \\ Qamer $^{\text {* }}$
}

1. Department of Zoology, Government College University, Faisalabad-Pakistan

2. National Integrated Pest Management Programme, Department of Plant and Environmental Protection, National

Agricultural Research Centre, Park Road Islamabad-Pakistan

*Corresponding author's email: saminabee@gmail.com

Citation

Muhammad Sajid, Tahira Yasmin, Farkhanda Asad and Samina Qamer. Changes in HMF content and diastase activity in honey after heating treatment. Pure and Applied Biology. Vol. 8, Issue 2, pp1668-1674.

http://dx.doi.org/10.19045/bspab.2019.80109

\begin{tabular}{llll}
\hline \hline Received: 24/04/2019 & Revised: 26/06/2019 & Accepted: 28/06/2019 & Online First: 30/06/2019 \\
\hline
\end{tabular}

\section{Abstract}

Like any other food items which are placed for sale, honey is one of them; therefore, its freshness is a matter of concern. Beekeepers usually use heat crystallized honey to make it more captivating to consumers. In this process honey is heated to degrade fructose to hydroxymethylfurfural (HMF). Heating also deactivate daistase enzyme in honey. This research is focused on enzyme degradation and estimation of changes in $\mathrm{HMF}$ content of honey (multi-floral \& acacia) due to thermal treatment performed at $4{ }^{\circ} \mathrm{C}, 25^{\circ} \mathrm{C}, 35^{\circ} \mathrm{C}, 45^{\circ} \mathrm{C}$ and $55^{\circ} \mathrm{C}$ temperatures for 4 and 8 hours. Both these quality parameters are one of the important indicators for freshness, storage and proper heating of honey. The samples of Multi-floral honey were collected from beekeepers of distinct areas of Punjab. Results were subjected to Statistical analysis. It was found that except $4{ }^{\circ} \mathrm{C}$ and $25^{\circ} \mathrm{C}$, the other temperatures caused rising of HMF content and lowering in diastase activity with different ratio depending upon duration of heating time.

Keywords: Diastase activity; European bee; Pakistani honey; Thermal treatment

\section{Introduction}

Honey is a supersaturated liquid of sugar, particularly glucose and fructose, with small amounts of other compounds like enzymes, dextrin, volatile oils, waxes, organic acids, albuminoidal gum substances, ethers and other minerals [1,2]. Vital quality parameters include Hydroxymethylfurfural or HMF which is a cyclic aldehyde $\left(\mathrm{C}_{6} \mathrm{H}_{6} \mathrm{O}_{3}\right)$ and is formed by the removal of water molecule from fructose and glucose in acidic medium and increases with temperature and storage time $[3,4]$. HMF is present only in small amounts in freshly prepared honey more or less reaching to zero. However, it further increases during the heating or storage processes. The formation of HMF mainly be influenced by the $\mathrm{pH}$ such as in the acidic nectar originated type honey it built more than in darker honeys with higher $\mathrm{pH}[5,6]$. Short time heat treatment causes only slight increase in HMF content even at higher temperature [7]. Additionally, a steady temperature dependent increase of HMF takes place upon storage of honey. Codex Alimentarius and EU standards set the maximum level of $\mathrm{HMF}$ is $40 \mathrm{mg} / \mathrm{kg}$, while honey taken from the tropics and blends with them should not have HMF level more than $80 \mathrm{mg} / \mathrm{kg}$. Beekeeping organizations of some 
countries have set a maximum limit of 15 $\mathrm{mg} / \mathrm{kg}$ for specially labelled "quality" or "virgin" honeys like Germany, Italy, Finland, and Switzerland. HMF can be used as a sign of honey quality and in all over the world recognized due to its capability to indicate the freshness or lack of freshness of honey [6]. Natural honey has various enzymes, which are either secreted directly by bee's salivary glands or found in the nectar or pollen. They are responsible for the conversion of nectar and honeydew to honey. The enzymes are amylases, invertases, glucosidases, catalases, phosphatases and other [8]. Among them, diastase is one of the important enzymes. It is thermally stable, starch-digesting $\alpha$ and $\beta$ amylase enzymes. The a-amylase splits the starch chain and make dextrin's, and the $\beta$ amylase separates the reducing sugar maltose from the ends of the starch chain [9]. This enzyme helps in conversion of starch to maltose and is added by bees during honey production [10]. Diastase is relatively resistant to heat and storage [11]. It is measured as Diastase Number (DN), which may be defined as "amount of enzyme, which will convert 0.01 gram of starch to the prescribed end-point in one hour at $40^{\circ} \mathrm{C}$ under the conditions of the test" [12]. It also serves as a sensitive indicator of the honey treatment and storage [4]. This research is aimed on studying the effect and variations caused due to heating treatment on thermolabile compounds in honey (HMF and diastase) as honey freshness parameter.

\section{Materials and methods}

A total of 25 fresh Pakistani Apis mellifera honey samples were collected directly from beekeepers from different areas i-e Sargodha, Faisalabad, Toba tak singh and Shahkot of Punjab, Pakistan during September to December 2017. 200g samples were packed in air-tight jars and kept at 5 different temperatures $\left(4^{\circ} \mathrm{C}, 25^{\circ} \mathrm{C}, 35^{\circ} \mathrm{C}, 45^{\circ} \mathrm{C}\right.$ and $55^{\circ} \mathrm{C}$ ) for 4 and 8 hours in a water bath to study the effect of temperature on its HMF content and diastase activity. After and during experiment samples were kept at room temperature $\left(25^{\circ} \mathrm{C}\right)$. No preservative was added at any stage. Samples were diluted in distilled water at room temperature according to the requirements of the test. Both biochemical tests were performed in triplicate. Estimation of hydroxymethylfurfural in honey was followed by Winkler method [13]. In this method honey solutions are mixed with $\mathrm{p}$ toluidine and barbituric acid solutions and the end color is measured against a blank in $1 \mathrm{~cm}$ cuvettes at $550 \mathrm{~nm}$. The content of HMF was calculated as $\mathrm{HMF}=192 \times \mathrm{A} \times 10 /$ weight of honey in grams. The results were expressed as $\mathrm{mg} / \mathrm{Kg}$. The method used to determine diastase activity is based on actual work of Schade [14]. Results are stated in Schade units per gram of honey. The method based on the principle "the enzyme in the sample under standard conditions acts upon a standard solution of starch, capable of developing, with iodine, a colour in a defined range of intensity". The decrease in the blue colour was measured at intervals. A plot of absorbance against time is used to determine the time tx required to reach the specified absorbance, 0.235 . The diastase activity is calculated as diastase number (DN) using this formula:

$$
\mathrm{DN}=\frac{60 \text { minutes }}{\mathrm{t}_{\mathrm{x}}} \times \frac{0.10}{0.01} \times \frac{1.0}{2.0}=\frac{300}{\mathrm{t}_{\mathrm{x}}}
$$

\section{Statistical analysis}

The data was statistically analyzed and tests were presented as mean $\pm \mathrm{SD}$. The results of these biochemical parameters were compared with standard values ANOVA (Table $1 \& 2$ ). Difference between means at $95 \%$ confidence level $(\mathrm{p}<0.05)$ were considered statistically significant (Steel and Tori, 1981). 
Table 1. Analysis of variance for HMF content

\begin{tabular}{|c|c|c|c|c|}
\hline Source of variation & $\begin{array}{c}\text { Degrees of } \\
\text { freedom }\end{array}$ & Sum of squares & Mean squares & F-value \\
\hline Temperature & 4 & 111768.354 & 27942.089 & $141.18^{* *}$ \\
Error & 120 & 23750.680 & 197.922 & \\
\hline Total & 124 & 135519.034 & & \\
\hline
\end{tabular}

$* *$ = Highly significant $(\mathrm{P}<0.01)$

Table 2. Analysis of variance for Diastase number

\begin{tabular}{|c|c|c|c|c|}
\hline Source of variation & $\begin{array}{c}\text { Degrees of } \\
\text { freedom }\end{array}$ & Sum of squares & Mean squares & F-value \\
\hline Temperature & 4 & 467.175 & 116.794 & $62.01 * *$ \\
Error & 120 & 226.003 & 1.883 & \\
\hline Total & 124 & 693.177 & & \\
\hline$*$ = Highly significant $(\mathrm{P}<0.01)$ &
\end{tabular}

\section{Results and discussion}

\section{Hydroxymethylfurfural (HMF) content}

For measuring honey quality HMF levels and diastase testing have been in use for over 75 years [15]. It is important to understand the effects of heat of pasteurization on aging and HMF levels due to importance of honey [16]. In current study HMF was well within the prescribed International limit at $4^{\circ} \mathrm{C}$ and $25^{\circ} \mathrm{C}$ after four and even eight hours heating. While increased in $35^{\circ} \mathrm{C}$ after eight hours heating and was closer to the prescribed standard. Rest of the two temperatures caused HMF content accumulation either close or beyond the set limit (Fig.1). The HMF content of 25 samples of Apis mellifera honey at $4{ }^{\circ} \mathrm{C}$ ranged between $2.88-28.99 \mathrm{mg} / \mathrm{kg}$ with a mean value of $14.43 \pm 1.85 \mathrm{mg} / \mathrm{kg}$ lie within the Codex Draft value and had fresh honey characteristics. At $25^{\circ} \mathrm{C}$ the HMF content was between 26.7 to $49.6 \mathrm{mg} / \mathrm{kg}$ with a mean value of $33.28 \pm 1.05 \mathrm{mg} / \mathrm{kg}$ compared to $18 \%$ increase from $35^{\circ} \mathrm{C}$ and $200 \%$ from $4^{\circ} \mathrm{C}$. All honey samples at $45{ }^{\circ} \mathrm{C}$ indicate raise of $77.7 \%$ from $35^{\circ} \mathrm{C}$ and $434 \%$ from $4^{\circ} \mathrm{C}$. However, highest $\mathrm{HMF}$ content $(96.83 \mathrm{mg} / \mathrm{kg}$ \pm 4.12 ) was found at $55^{\circ} \mathrm{C}$ among all the temperature ranges that was more $25.5 \%$ from $45^{\circ} \mathrm{C}, 190 \%$ from $25^{\circ} \mathrm{C}, 122 \%$ from $35^{\circ} \mathrm{C}$, and $571 \%$ from $4^{\circ} \mathrm{C}$. The result obtained from the present study regarding HMF content accumulation with increasing temperature has also been reported by other authors. Microwave heating slightly influenced on hydroxymethylfurfural content in the tested honey samples in comparison with conventional heating approach depending upon heating time and temperature ranges [17]. [18] Found $2.3 \mathrm{mg} / \mathrm{kg}$ to $17.8 \mathrm{mg} / \mathrm{kg}$ kept at $20-25^{\circ} \mathrm{C}$ in Brazilian Pampa biome honey, 12.07 to 27.43 $\mathrm{mg} / \mathrm{kg}$ by [19] in six Tunisian honeys kept at $20^{\circ} \mathrm{C}$ and $15.14 \mathrm{mg} / \mathrm{kg}$ to $54.06 \mathrm{mg} / \mathrm{kg}$ at 45 ${ }^{\circ} \mathrm{C}$ by [20]. These findings are in agreement with present studies. Changes in HMF were recorded about 9 times higher than nonheated honey after heating acacia honey at $100^{\circ} \mathrm{C}$ by $[21,22]$ reported HMF content of honey samples heated at $35^{\circ} \mathrm{C}$ ranged between $79.2 \mathrm{mg} / \mathrm{kg}$ to $238.4 \mathrm{mg} / \mathrm{kg}$ higher than observed in present study at same temperature. [15] also observed gradual increase in $\mathrm{HMF}$ level during heating treatment at $50^{\circ} \mathrm{C}, 70^{\circ} \mathrm{C}$ and $100^{\circ} \mathrm{C}$. [23] determined $\mathrm{HMF}$ content in Apis mellifera honey samples ranged between $4-9 \mathrm{mg} / \mathrm{kg}$ much lower than found in present study at same temperature. The low (2.63$2.85 \mathrm{mg} / \mathrm{kg}$ ) HMF content were reported by [3]. The overall increase of HMF content at 
$25^{\circ} \mathrm{C}$ is $130 \%$ from $4^{\circ} \mathrm{C}$ but did not exceeds the prescribed limit. So, honey samples at room temperature seem to be of good quality i.e. $\leq 60 \mathrm{mg} / \mathrm{kg}$ (Table 3$)$.

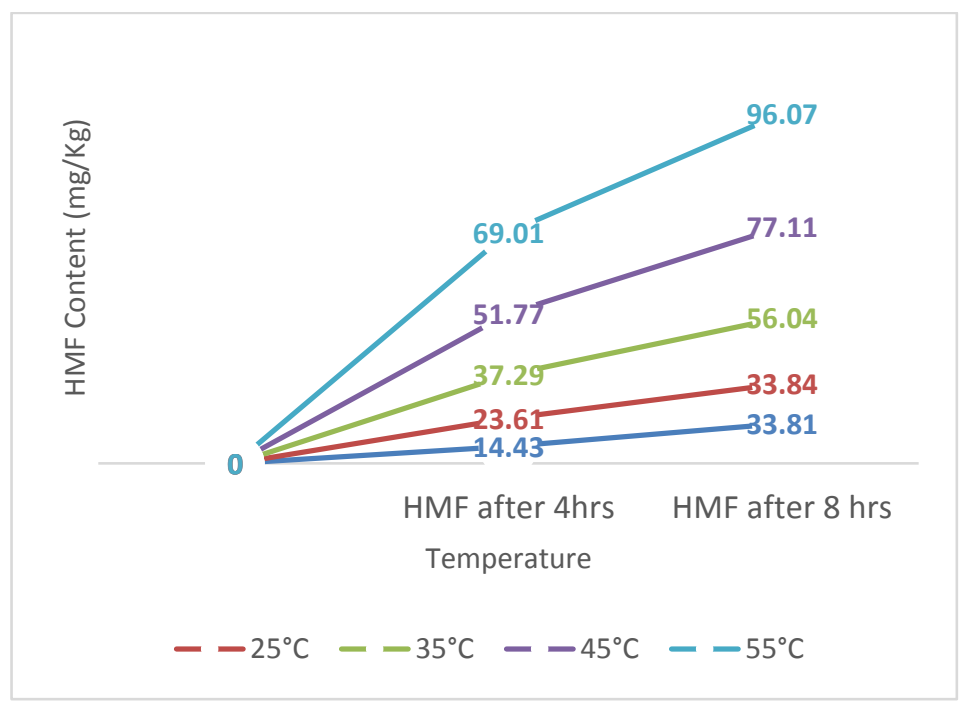

Figure 1. Variation of HMF Content at different temperatures

Table 3. International standard for HMF content and diastase activity of honey

\begin{tabular}{|c|c|c|c|c|}
\hline S. No. & Parameters & Codex draft 1999 & Directive 2001/EC & EU draft 1999 \\
\hline 1 & HMF content $(\mathrm{mg} / \mathrm{kg})$ & $\leq 60$ & $\leq 60$ & $\leq 40$ \\
\hline 2 & Diastase Number $(\mathrm{DN})$ & $\geq 8$ & $\geq 8$ & $\geq 8$ \\
\hline
\end{tabular}

\section{Diastase activity}

The honey proteins consist of mainly enzymes, reviewed by White [24]. One of them is diastase which digests starch to form maltose. Its heat resistant property makes it important for indicating of honey quality and is used as meter of honey freshness. Value of 8 diastase units is set in the Codex Alimentarius and the European honey directive. Its deterioration depends upon storage and heat [25]. This enzyme activity in honey samples kept at $4{ }^{\circ} \mathrm{C}$ recorded in the range between $10.7 \mathrm{DN}$ to $23 \mathrm{DN}$ with mean value of 14.07DN \pm 0.464 (Fig. 2). [26] found diastase activity from $9^{\circ} \mathrm{G}$ to $23.3^{\circ} \mathrm{G}$. Decline of $16 \%$ in enzyme activity has been recorded from $4^{\circ} \mathrm{C}$ to $25^{\circ} \mathrm{C}$ in present study (10DN13.6DN) which was lower as compared to [23] at same temperature. Moreover, a few honey samples either didn't show any change or small loss in diastase activity as also noticed by [27] at $25^{\circ} \mathrm{C}$. The value of diastase activity was within the Codex Standards at $25^{\circ} \mathrm{C}$ i.e. $\leq 8 \mathrm{DN}$. [28] found $\mathrm{DA}$ in strawberry samples of honey with the mean value of 3.58 Go the degrees stored at room temperature $(20 \pm 3 \circ \mathrm{C})$. Enzymatic activity mainly depends upon geographic and floral origins of the product, also on its freshness [29]. The DA range was $8.7-12.5 \mathrm{DN}, 8.5-$ 10DNand $6.9-8.82 \mathrm{DN}$ at $35^{\circ} \mathrm{C}, 45^{\circ} \mathrm{C}$ and $55^{\circ} \mathrm{C}$, respectively. So, the loss of enzymatic activity was $25 \%, 34 \%$ and $37 \%$ more compared to $4^{\circ} \mathrm{C}$ after 4 hour's thermal treatment. [23] reported $23-32 \mathrm{DN}$ range at $30^{\circ} \mathrm{C}$. The declining behavior in activity expressed by diastase enzyme at higher temperature $\left(55^{\circ} \mathrm{C}\right)$ in the present study has also been reported [3] where $61-70 \%$ loss of diastase activity was observed in honey samples heated at $55^{\circ} \mathrm{C}$ for 3-15 minutes. [30] compared the microwave heating and 
conventional thermal approach to study the inactivation of diastase activity in Polish Honey. [31] Did not found that short term heating at $55,65,75 \circ \mathrm{C}$ for $5,15,20,25$ minutes does not affect the diastase activity. [32] Found 5.73 to $16.64 \mathrm{DN}$ kept at $4^{\circ} \mathrm{C}$ being lowest in citrus and highest in zizipus honey collected from Punjab and KPK provinces of Pakistan. These DN values are lower than present investigation at same $4^{\circ} \mathrm{C}$. [33] documented less DA (14.50DN) in $A$. mellifera honeys. Sajid et al. [34] quantified Diastase activity 34.39(DN) at room temperature in Pakistani honey from various floral sources.

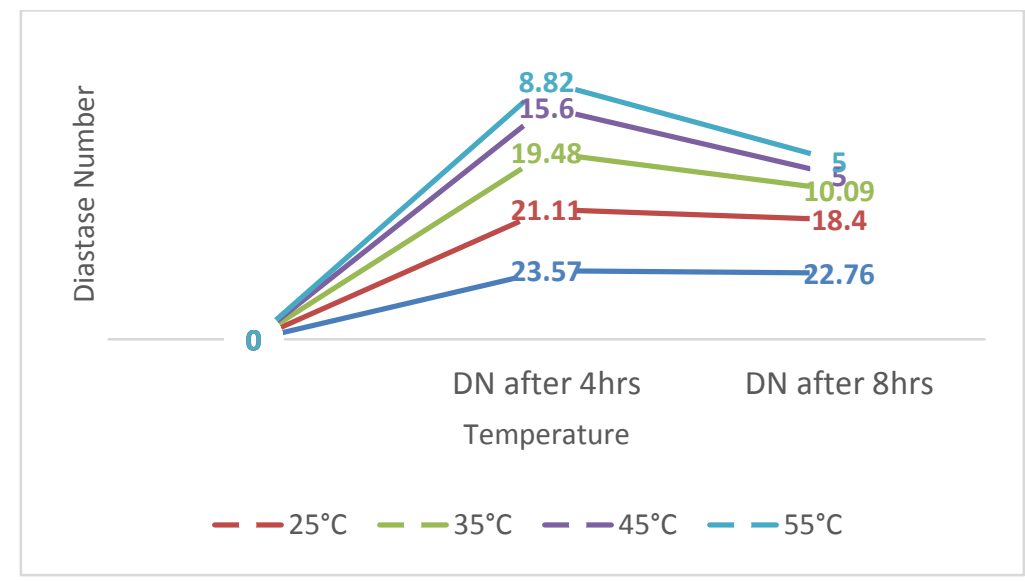

Figure 2. Variation of DN at different temperatures

\section{Conclusion}

Many of the components of honey are unstable over time and are thermolabile. Therefore, it can be concluded that temperatures causes drop in enzymatic activity significantly. Moreover, high temperature also resulted in increase in HMF content making honey possibly unfit to consume.

\section{Authors' contributions}

Conceived and designed the experiments: $\mathrm{S}$ Qamer, Performed the experiments: M Sajid, Analyzed the data: T Yasmin, Contributed reagents/ materials/ analysis tools: F Asad \& S Qamer, Wrote the paper: M Sajid \& S Qamer.

\section{References}

1. Ansari MA, Al-Ghamdi A, Khan KA, Adgaba N, El-Ahmady SH, Gad HA, Roshan AR, Sultan AM, Kolyali S (2018). Validation of botanical origins and geographical sources of some Saudi honeys using ultraviolet spectroscopy and chemometric analysis. Saudi $J$ of Biolog Sci 25: 377-382.

2. Sereia MJ, Março PH, Perdoncini MRG, Rejane S, Parpinelli RS, Gomes de LE \& Anjo FA (2017). Techniques for the Evaluation of Physicochemical Quality and Bioactive Compounds in Honey. http://www.intechopen.com/books/hone $\mathrm{y}$-analysis

3. Cervantes CMA, Gonalez NSA \& Sauri DE (2000). Effect of temporary thermic treatment of honey on variation of the quality of the same during storage. Apicata, 35: 162-170.

4. Da Silva PM, Gauche C, Gonzaga LV, Costa ACO \& Fett R 2016. Honey: Chemical composition, stability and authenticity. Food Chem 196: 309-323.

5. Thyrasyvoulou AT (1986). The use of $\mathrm{HMF}$ and diastase criteria of quality of Greek Honey. J of Apicul Res 25(3): 186195. 
6. Bogdanov S 2011. Honey Composition. The Honey Book, Chapter 5. Bee Product Sci pp 1-10.

7. Subramanian R, Hebbar HU \& Rastogi NK (2007). Processing of honey: A review. Inter J of Food Properties 10(1): 127-143.

8. Voldrich M, Rajchl A, Cizkova H \& Cuhra P (2009). Detection of Foreign Enzyme Addition into the Adulterated Honey. Czech J of Food Sci 27: 280-282.

9. Crane E (1975). Honey: A Comprehensive Survey. International Bee Research Association, Heinemann, London, UK, pp 181-202.

10. Kamal A, Raza S, Rashid S, Hameed T, Gailani M, Qureshi MA \& Nasim K (2002). Comparative study of honey collected from different flora of Pakistan. Online J of Biolog Sci 2: 626627.

11. Bogdanov S (2009). Physical properties of honey. In: Book of Honey, Chapter 4. Bee Product Sci.

12. Vorlova L \& Pridal A (2002). Invertase and diastase activity in honeys of Czech provenience. Acta Univarsitatis Agriculturae et Silviculturae Mendelianae Brunensis, 5: 57-66.

13. Winkler O (1955). Beitrag zum Nxhweis und zur Bestimmung von Hydroxymethylfurfural in Hoing und Kunsthonig. Z Lebensm Unters Forsch 102: 160-167.

14. Schade JE, Marsh GL \& Eckert JE (1958). Diastase activity and hydroxymethylfurfural in honey and their usefulness in detecting heat adultreration. Food Res 23: 446-463.

15. Fallico B, Zappala M, Arena E \& Verzera A (2004). Effects of conditioning on HMF content in unifloral honeys. Food Chem 85: 305313.

16. Leblanc BW, Eggleston G, Sammataro D, Cornett C, Dufault R, Deeby T, \& Cyr
ES (2009). Formation of Hydroxymethylfurfural in Domestic High-Fructose Corn Syrup and Its Toxicity to the Honey Bee (Apis mellifera). J Agri. Food Chem (57): 7369-7376.

17. Al-Diab D \& Jarkas. B. (2015). Effect of storage and thermal treatment on the quality of some local brands of honey from Latakia market. $J$ of Entomol and Zool Studies 3(3): 328-334.

18. Cruz LC, Batista JES, Zemolin APP, Nunes MEM, Lippert DB, Royes LFF, Soares F A, Pereira AB, Posser T \& Franco JL (2014). A Study on the Quality and Identity of Brazilian Pampa Biome Honey: Evidences for Its Beneficial Effects against Oxidative Stress and Hyperglycemia. Inter $J$ of Food Sci 1-11.

19. Boussaid A, Chouaibi M, Rezig L, Hellal R., Dons1 F, Ferrari G \& Hamdi S (2014). Physicochemical and bioactive properties of six honey samples from various floral origins from Tunisia. Arabian $\mathrm{J}$ of Chem xxx: xxx-xxx.

20. MarchinI LC, Camargo AC, Moreti C, Otsuk IV \& Sodré GS (2007). Physicochemical composition of Apis mellifera honey samples from são paulo state, Brazil. Quimica Nova 30: 16531657.

21. Lawal RA, Lawal, AK \& Adekalu, JB (2009). Physico-chemical Studies on Adulteration of Honey in Nigeria. Pak J of Biological Sci 12(15): 1080-1084.

22. Fallico B, Arena E \& Zappala M (2008). Prediction of honey shelf life. $J$ of Food Quality 32: 352-368.

23. Qamer S \& Shakoori AR (2004). Increased hydroxymethylfurfural and decreased diastase activity as indicators of degradation of quality of honey. PakJ of Zool 36(2): 165-166.

24. White, J. W (19750). Composition of honey., In Crane, E (ed.) Honey, a 
comprehensive survey, Heinemann Edition; London; pp 157-206.

25. Bogdanov S (2011). Honey composition. In S. Bogdanov (Ed.), The honey book pp 27-36. Retrieved from http://www.bee-hexagon.net/honey/.

26. Nanda V, Bera MB \& Bakhshi AK (2005). Optimization of the process parameters to test the quality attributes of hydroxymethylfurfural content and diastatic activity of Sunflower (Helianthus annus) honey using response surface methodology. Europ Food Res and Technol 222: 64-70.

27. Tosi E, Martinet R, Ortega M, Lucero HA \& Ré E (2008). Honey diastase activity modified by heating. Food Chem 106(3): 883-887.

28. Ulloa PA, Maia IM \& Brigas AF (2015). Physicochemical Parameters and Bioactive Compounds of Strawberry Tree (Arbutus unedo L.) Honey. $J$ of Chem http://dx.doi.org/10.1155/2015/602792.

29. Gomes S, Dias LG, Moreira LL, Rodrigues P \& Estevinho L (2010). Physicochemical, microbiological and antimicrobial properties of commercial honeys from Portugal. Food and Chemical Toxicol 48(2): 544-548.

30. Kowalski S, Lukasiewicz M, Bednarz S \& Panuś M (2012). Diastase number changes during thermal and microwave processing of honey. Czech J Food Sci 30: 21-26.

31. Hasan SH (2013). Effect of Storage and Processing Temperatures on Honey Quality. J of Babylon University/Pure and Appl Sci 6(21): 2244-2253.

32. Khan KA, Al-Ghamdi AA \& Ansari MJ (2016). The characterization of blossom honeys from two provinces of Pakistan. Ital J Food Sci 28: 625-638.

33. Iftikhar F, Masood MA \& Waghchoure ES 2011. Comparison of Apis cerana,Apis dorsata, Apis florea and Apis mellifera. Honey from Different Areas of Pakistan. Asian J Exp Biol Sci 2(3): 399.

34. Sajid M, Yamin M, Asad F, Yaqub S, Ahmad S, Ali M, Mubarik MS, Ahmad B, Ahmad W \& Qamer S (2019). Comparative study of physio-chemical analysis of Fresh and Branded honeys from Pakistan. Saudi J of Biol Sci 30(40): 30 . 